\title{
The Influence of Discipline, Work Environment, and Work Commitment on Job Satisfaction
}

\author{
Sherly Ong ${ }^{*}$, Hendry ${ }^{2}$, Vivi Winata ${ }^{3}$, Monika ${ }^{4}$
}

1,2,3,4 Fakultas Ekonomi dan Bisnis, Universitas Prima Indonesia, Medan, Indonesia

\section{ART ICLE IN F O}

Article history:

Received March 19, 2021

Revised April 03, 2021

Accepted May 01, 2021

Available online May 25, 2021

Keywords:

discipline, work environment, work commitment, job satisfaction of employees

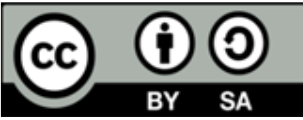

This is an open access article under the CC BY-SA license.

Copyright $@ 2021$ by Author. Published by Universitas Pendidikan Ganesha.

\begin{abstract}
A B S T R A C T
This study aims to analyze discipline, work environment, and commitment to job satisfaction. This type of research is quantitative research. The population in this study found 66 employees. The number of samples in this study was 66 employees. In this study, data collection related to the problems studied by researchers was carried out through questionnaires distributed to employees at the company, interviews were conducted to employees, and documentation studies in the form of company data, books, and journals related to the variables studied. Sources of research data consist of primary data in this study are interviews and questionnaires and secondary data is data obtained from notes, books, and magazines in the form of financial reports for company publications, government reports, articles, books as theory, magazines, and so on. The data analysis used is classical assumption test and hypothesis testing. The results showed that the coefficient of determination can be seen from the Adjusted R Square value of 0.561 , meaning that $56.1 \%$ of the variation in job satisfaction variables can be explained by variations in work discipline, work environment, and commitment variables. while the remaining $43.9 \%$ is explained by other variables not examined in the study. So, it can be concluded that discipline, work environment, and work commitment have a positive effect on job satisfaction.
\end{abstract}

\section{INTRODUCTION}

Performance in general are activities and results that can be achieved or continued by a person or group of people in doing a good job task, meaning that it achieves the goals or work standards that have been set before and after or can exceed the standards used by the company during a certain period (Thamotharan et al., 2021; Yasa et al., 2021). Performance is also a description of the level of achievement of the implementation of an activity or policy in realizing the goals, objectives, mission and vision of the organization contained in the strategic plan of an organization. The success of a job is largely determined by effective human resources (Daulay et al., 2019), Human resources have a major role in the activities of the organization or the job. Assessment of human resources can be seen from the work that has been done through the performance it produces. So that it can be said that effective human resources produce a good performance. The importance of paying attention to employee performance is because performance is one of the determinants in achieving company performance in an effort to achieve company goals.

The performance of each employee will have different levels of results. In the scope of human resources, the performance of an employee is needed to achieve the best performance, both for the employees themselves and the company. To get a satisfactory performance as expected by the company, of course, it is necessary to have supporting factors so that maximum employee performance can be achieved. Factors that affect employee performance are effectiveness and efficiency, authority and responsibility, discipline, initiative. The discipline of a company is said to be good if most of the employees obey the existing regulations (Kale et al., 2019; Suryani, 2020). Every company or organization will definitely hold an evaluation to find out what are the obstacles and deficiencies that exist so that they can be improved in order to achieve the goals of the company or organization. Someone who is in a company or organization must have full loyalty in order to be able to have a vision and mission to achieve common goals.

However, in reality, what happened at PT Ria Multi Solusindo Medan, it is known that employees do not have a good commitment to the organization due to the incompatibility of employee expectations with the reality obtained. This company does not take care of its employees so that employees cannot be 
loyal to the company. This can be seen from the increase in employee turnover in this company. This employee disloyalty is due to the company not providing what has been promised to employees in the form of salary increases every year but in practice, the company does not increase every year and the company is not committed to the rules within the company where there is injustice in giving sanctions to employees who violate so that this causes the disappointment of employees and prefers to resign due to low commitment from the company to employees. The level of work discipline of employees at this company has also decreased as seen from the number of jobs that are not completed on time, the absentee level has increased and the number of employees who are late to the office In addition, the work environment at this company is still not good, such as the mandatory health protocol for masks and hand washing that have not been strictly enforced for all employees, the level of cleanliness is still not maintained in the company environment, the working relationship of employees is still not harmonious.

The problems that occur certainly need to be the company's attention. Commitment is a relationship between individual employees and work organizations, where employees have confidence and trust in the values and goals of the work organization (Darmawati, 2016). Employees who have a high level of commitment to their organization tend to stay as members for a relatively long time, feeling the company is a part of their lives so that they will work optimally to improve their performance in the company. Whereas commitment is an important thing in an organization. Commitment can reflect the degree to which an individual identifies with the organization and is bound to its goals. In addition, commitment is also an employee's feeling to be part of an organization or company and recognizes the goals, values, norms, and ethical standards in an organization and expresses commitment and intends to maintain membership in the organization. Commitment is also a strong desire to be a member of a group, a high willingness to work for the organization, a certain belief, and acceptance of the values and goals of the organization. Commitment can also affect the job satisfaction of an employee. In addition to commitment, other factors can affect employee job satisfaction, including discipline and work environment (Hutagalung \& Ritonga, 2018; et al., 2018).

Discipline is an important factor in regulating the behavior and ways of working of members of the organization (Jaka et al., 2013). These rules are in the form of a set of values and norms that have been agreed upon by members of the organization to regulate how members of the organization behave in carrying out organizational activities. So, every company or organization needs a competitive advantage to achieve its goals. The work environment is everything that is around employees that can affect the implementation of work. The work environment is the entire work facilities and infrastructure that exist around employees who are doing work that can affect the implementation of the work including the workplace, facilities, cleanliness, lighting, tranquility, including the working relationship between the people in the place (Hafid \& Hasanah, 2016). The increase in employee job satisfaction is caused by work discipline, work commitment, and work environment. Job satisfaction is a factor that will contribute to improving organizational performance. Job satisfaction is the result of various attitudes related to work and specific factors such as wages, supervision, job stability, job security, opportunities for advancement, fair job evaluation, social relations at work, and superior treatment (Prabowo \& Romadlon, 2020; Sintaasih \& Astitiani, 2019).

Several studies relevant to this study were conducted by (Bentar et al., 2017) who found that leadership, motivation, work discipline and work environment on the performance of the employees of Taman Botani Sukorambi (TBS) Jember. Then another study found that the variables of job satisfaction and work discipline together had a positive effect on the performance of the employees of Bank Rakyat Indonesia Putri Hijau Medan Branch (Arda, 2017). Another study found that work motivation, work discipline, and leadership style were shown to simultaneously have a positive and significant effect on the performance of St. Hospital's employees. Carolus Summarecon Serpong (Palupi J, 2018). This study aims to analyze discipline, work environment, and work commitment to employee job satisfaction.

\section{METHODS}

This type of research is quantitative research. This research will be conducted at PT Ria Multi Solusindo Medan. The population in this study amounted to 66 employees. The number of samples in this study was 66 employees. In this study, data collection related to the problems studied by researchers was carried out through questionnaires distributed to employees at the company, interviews were conducted to employees, and documentation studies in the form of company data, books, and journals related to the variables studied. Sources of research data consist of primary data in this study are interviews and questionnaires and secondary data is data obtained from notes, books, and magazines in the form of financial reports for company publications, government reports, articles, books as theory, magazines, and so on. The data analysis used is the classical assumption test and hypothesis testing. 


\section{RESULTS AND DISCUSSIONS}

Hypothesis testing used in this research is by using multiple linear regression analysis. The results of Multiple Linear Regression Analysis can be seen in Table 1.

Table 1. Results of Multiple Linear Regression Analysis

\begin{tabular}{|c|c|c|c|c|c|c|}
\hline \multirow[t]{2}{*}{ Model } & & \multicolumn{2}{|c|}{ Unstandardized Coefficients } & \multirow{2}{*}{$\frac{\text { Standardized Coefficients }}{\text { Beta }}$} & \multirow[b]{2}{*}{$\mathrm{t}$} & \multirow[b]{2}{*}{ Sig. } \\
\hline & & B & Std. Error & & & \\
\hline \multirow[t]{4}{*}{1} & (Constant) & .072 & 2.306 & & .031 & .975 \\
\hline & Discipline & .099 & .049 & .172 & 2.009 & .049 \\
\hline & Work Environment & .431 & .075 & .556 & 5.716 & .000 \\
\hline & Work Commitment & .162 & .066 & 232 & 2.465 & .016 \\
\hline
\end{tabular}

The results of hypothesis testing indicate that a constant of 0,072 states that if there is no or constant then the variables of work discipline, work environment, and commitment then job satisfaction is 0,072 units. The regression coefficient for the work discipline variable is 0,099 and is positive, this means that if each increase in the work discipline variable by 1 unit, it will increase the job satisfaction variable by 0,099 units assuming the other variables are fixed. The regression coefficient of the work environment variable is 0,431 and is positive, this means that if every 1 unit increase in the work environment variable will increase the job satisfaction variable by 0,431 units assuming the other variables are fixed. The regression coefficient for the commitment variable is 0,162 and is positive, this means that if each increase in the commitment variable by 1 unit, it will increase the job satisfaction variable by 0,162 units with the assumption that the other variables remain constant.

\section{Hypothesis Determination Coefficient}

The results of the coefficient determination test can be seen in Table 2 .

Table 2. Coefficient of Determination Test

\begin{tabular}{|c|c|c|c|c|}
\hline \multirow[t]{2}{*}{ Model } & \multicolumn{4}{|c|}{ Std. Error of the } \\
\hline & $\mathrm{R}$ & R Square & Adjusted R Square & Estimate \\
\hline dimension0 1 & $.763^{a}$ & .581 & .561 & 4.14941 \\
\hline
\end{tabular}

The results of the determination coefficient test can be seen from the Adjusted R Square value of 0.561 this means $56.1 \%$ of the variation in job satisfaction variables which can be explained by variations in work discipline, work environment, and commitment variables while the remaining 43.9\% (100\% $56,1 \%$ ) is explained by other variables not examined in this study, such as workload, leadership, work motivation and so on.

\section{Simultaneous Hypothesis Testing (F Test)}

The F statistic test shows whether all the independent variables included in the model have a simultaneous effect on the dependent variable. The result of the F test can be seen on Table 3.

Table 3. Result of F test

\begin{tabular}{llccccc}
\hline Model & & Sum of Squares & $\mathrm{df}$ & Mean Square & $\mathrm{F}$ & Sig. \\
\hline \multirow{2}{*}{1} & Regression & 1482.948 & 3 & 494.316 & 28.710 & $.000^{\mathrm{a}}$ \\
\cline { 2 - 7 } & Residual & 1067.492 & 62 & 17.218 & & \\
\cline { 2 - 7 } & Total & 2550.439 & 65 & & & \\
\hline
\end{tabular}

The test results obtained the calculated $F$ value (28.710) $>F$ table (2.75) and a significant probability of $0.000<0.05$, meaning that $\mathrm{Ha}$ is accepted and Ho is rejected, namely simultaneously Discipline, Work Environment and Work Commitment have a positive and significant effect on Job Satisfaction Employees of PT Ria Multi Solusindo Medan. 


\section{Partial Hypothesis Testing ( $t$ Test)}

The $t$ test is used to determine whether there is a significant (significant) relationship or influence between the independent variables partially on the dependent variable. The results of the test can be seen in Table 4.

Table 4. The result of the t-test

\begin{tabular}{|c|c|c|c|c|c|c|}
\hline \multirow[t]{2}{*}{ Model } & & \multicolumn{2}{|c|}{ Unstandardized Coefficients } & \multirow{2}{*}{$\begin{array}{c}\text { Standardized Coefficients } \\
\text { Beta }\end{array}$} & \multirow[b]{2}{*}{$\mathrm{t}$} & \multirow[b]{2}{*}{ Sig. } \\
\hline & & $\mathrm{B}$ & Std. Error & & & \\
\hline \multirow[t]{4}{*}{1} & (Constant) & .072 & 2.306 & & .031 & .975 \\
\hline & Discipline & .099 & .049 & 172 & 2.009 & .049 \\
\hline & Work Environment & .431 & .075 & .556 & 5.716 & .000 \\
\hline & Work Commitment & .162 & .066 & .232 & 2.465 & .016 \\
\hline
\end{tabular}

The results of the calculation of partial hypothesis testing obtained tcount $>$ ttable or 2,009 > 1.999 and significant obtained $0.049<0.05$, meaning that Ha is accepted and Ho is rejected, namely partially Discipline has a positive and significant effect on Employee Job Satisfaction at PT Ria Multi Solusindo Medan. The results of the calculation of partial hypothesis testing obtained tcount $>$ ttable or $5.716>1.999$ and significant obtained $0.000<0.05$, meaning that Ha is accepted and Ho is rejected, namely partially the Work Environment has a positive and significant effect on Employee Job Satisfaction at PT Ria Multi Solusindo Medan. The results of the calculation of partial hypothesis testing obtained tcount $>$ ttable or 2,465 $>1.999$ and significant obtained $0.016<0.05$, meaning that Ha is accepted and Ho is rejected, namely partially Work Commitment has a positive and significant effect on Employee Job Satisfaction at PT Ria Multi Solusindo Medan.

\section{Discussion}

Discipline is the willingness of employees to comply with all applicable regulations in the workplace, both written and unwritten regulations. This discipline is required by all employees of the company. Work discipline is an important thing to examine. because employees who have high discipline will have an impact on the performance of these employees. Because with the enforcement of discipline, especially for employees, it will be easy to achieve the organizational goals that have been set. Good employee discipline will also help achieve organizational goals, while low discipline will slow down the achievement of organizational goals. For this reason, work discipline in the company needs to be enforced, because with discipline there will be written rules that must be carried out and obeyed by all employees, both superiors and subordinates. The purpose of work discipline is to foster work discipline, for the sake of the continuity of the company in accordance with the company's motives, namely so that workers comply with all labor regulations and policies as well as applicable company regulations and policies, both written and unwritten, and carry out management orders; in order to be able to use and maintain the facilities and infrastructure, goods and services of the company as well as possible; so that they can act and behave in accordance with the norms that apply to the company, and so that the workforce is able to produce high productivity in accordance with company expectations, both in the short and long term. The functions of discipline include managing shared life, building personality, training personality, coercion, punishment, and creating a conducive environment. The results of this study are supported by previous research on work discipline affecting employee job satisfaction which found that work discipline had an influence on employee job satisfaction (Buntarti \& Udjang, 2015; Dewi \& Khotimah, 2020; Harjanti \& Mahmudah, 2018; Manik, 2017).

Partially the work environment has a positive and significant effect on employee job satisfaction. The work environment is everything that is around employees that can affect the implementation of work. The work environment is the overall work facilities and infrastructure that exist around employees who are doing work that can affect the implementation of the work including the work environment, facilities, cleanliness, lighting, tranquility, including the working relationship between the people in the place. The implementation of the discipline factor within the company will assist employees in directing and guiding them so that employee behavior in carrying out activities can be controlled, whether it has been carried out in accordance with the agreed rules which are expected to make employees responsible and timely in completing the expected work. this will have an impact on improving employee performance within the company. Furthermore, the company must also analyze the discipline factors of employees, and if there are negative things that occur in the implementation of discipline, it is necessary to make improvements 
and improvements to these employees. For this reason, this assessment is positive reciprocity between the company and employees which is expected to provide motivation in a better direction in carrying out discipline within the organization. The results of this study are supported by research conducted by (Viotti et al., 2020) found that there is a relationship between psychosocial characteristics of the work environment and job satisfaction. Then another research conducted found that there is organizational attachment and all its dimensions including the work environment are positively related to job satisfaction (Ampofo, 2020).

Work commitment has a positive and significant effect on employee job satisfaction at PT Ria Multi Solusindo Medan. If employees have a good commitment in the company, it will encourage the achievement of organizational goals, because they are supported by employees who are loyal or loyal in carrying out their work, actively participating in the involvement of every job so that employee performance is also expected to increase. Employees who have a high commitment can carry out the tasks assigned to them and carry them out and show their business with full responsibility. Employees who have organizational commitment are employees who are actively involved in the organization and are active in achieving organizational goals. There are three components of organizational commitment, namely affective commitment, continuance commitment, and normative commitment. Affective commitment is measured by three things, namely the employee's sense of belonging to the organization, the employee's emotional attachment to the organization, and the employee's sense of family towards the organization. Continuance commitment is related to the awareness of members about investment (everything that is considered valuable to employees such as time, effort, money that must be given up if leaving the organization), alternatives (possibility of joining another organization) and consideration (the time when members of the organization reach awareness about the impact of the investment). and alternatives). Normative commitment is an attachment to continue to be in the organization because they feel they have to be in the organization, normative commitment develops because the organization provides something very valuable and cannot be reciprocated by members of the organization. The results of this study are supported by research conducted by (Wolomasi et al., 2019) found that teacher job satisfaction was positively and significantly influenced by primary school teacher work commitment. Then another research conducted found that the higher the compensation and organizational commitment, the higher the employee morale (Darmawan \& Wibawa, 2019).

\section{CONCLUSION}

Discipline has a positive and significant effect on employee job satisfaction at PT Ria Multi Solusindo Medan, partially the work environment has a positive and significant effect on employee job satisfaction at PT Ria Multi Solusindo Medan, partially work commitment has a positive and significant effect on employee job satisfaction at PT Ria Multi Solusindo Medan Simultaneously Discipline, Work Environment and Work Commitment have a positive and significant effect on Job Satisfaction of Employees of PT Ria Multi Solusindo Medan. The implications of this study are to reinforce company rules, improve a comfortable and conducive work environment and increase employee salaries and promotions. For further researchers, to add other variables outside of the variables studied by researchers such as workload, leadership, work motivation, and so on.

\section{REFERENCES}

Ampofo, E. T. (2020). Mediation effects of job satisfaction and work engagement on the relationship between organisational embeddedness and affective commitment among frontline employees of star-rated hotels in Accra. Journal of Hospitality and Tourism Management, 44(April), 253-262. https://doi.org/10.1016/j.jhtm.2020.06.002.

Arda, M. (2017). Pengaruh Kepuasan Kerja Dan Disiplin Kerja Terhadap Kinerja Karyawan Pada Bank Rakyat Indonesia Cabang Putri Hijau Medan. Jurnal Ilmiah Manajemen Dan Bisnis, 18(1), 45-60. https://doi.org/10.30596/jimb.v18i1.1097.

Bentar, A., Purbangkaro, M., \& Prihartini, D. (2017). Analisis Pengaruh Kepemimpinan, Motivasi, Disiplin Kerja dan Lingkungan Kerja Terhadap Kinerja Karyawan Taman Botani Sukorambi ( TBS ) Jember. Jurnal Manajemen dan Bisnis Indonesia, 3(1), 1-17. https://doi.org/https://doi.org/10.32528/jmbi.v3i1.780.

Buntarti, R. S., \& Udjang, R. (2015). Kompensasi dan Disiplin Kerja pada Kinerja Karyawan dengan lama bekerja sebagai Variabel Kontrol. Jurnal Perilaku Dan Strategi Bisnis, 3(2), 1-9. https://doi.org/https://doi.org/10.26486/jpsb.v3i2.458.

Darmawan, I. G. W., \& Wibawa, I. M. A. (2019). Pengaruh Kompensasi Finansial, Lingkungan Kerja Non Fisik, Dan Komitmen Organisasional Terhadap Semangat Kerja Karyawan. E-Jurnal Manajemen Universitas 
https://doi.org/https://doi.org/10.24843/EJMUNUD.2019.v08.i08.p15.

Darmawati, A. (2016). Pengaruh Kepuasan Kerja Terhadap Organizational Citizenship Behavior Dengan Komitmen Organisasi Sebagai Variabel Mediasi. Jurnal Ilmu Manajemen, 13(1). https://journal.uny.ac.id/index.php/jim/article/view/22220/11463.

Daulay, R., Kurnia, E., \& Maulana, I. (2019). Analisis Faktor-Faktor Yang Mempengaruhi Kinerja Karyawan Pada Perusahaan Daerah di Kota Medan. Proseding Seminar Nasional Kewirausahaan, 1(1), 209218. https://doi.org/https://doi.org/10.30596/snk.v1i1.3612 Analisis.

Dewi, R., \& Khotimah, S. H. (2020). Pengaruh Profesionalisme Dan Disiplin Kerja Guru. ELEMENTARY Islamic Teacher Journal, 8(2), https://doi.org/http://dx.doi.org/10.21043/elementary.v8i2.7839.

Hafid, M., \& Hasanah, U. (2016). Persepsi Lingkungan Kerja Psikologis Terhadap Kepuasan Kerja. Journal An-Nafs: Kajian Penelitian Psikologi, 1(2), 269-290. https://doi.org/10.33367/psi.v1i2.294.

Handoko, D. S., \& Rambe, M. F. (2018). Pengaruh Pengembangan Karir dan Kompensasi terhadap Komitmen Organisasi Melalui Kepuasan Kerja. Maneggio: Jurnal Ilmiah Magister Manajemen, 1(1), 31-45. https://doi.org/10.30596/maneggio.v1i1.2238.

Harjanti, R. S., \& Mahmudah, N. (2018). Lingkungan kerja, kedisiplinan, motivasi dan diklat dalam upaya meningkatkan produktivitas kerja dosen politeknik harapan bersama tegal. Jurnal MONEX, 7(1), 368-372. https://doi.org/http://dx.doi.org/10.30591/monex.v7i1.757.

Hutagalung, I., \& Ritonga, R. (2018). Pengaruh Iklim Komunikasi dan Komitmen Organisasi Terhadap Kepuasan Kerja Pegawai Kecamatan XYZ Bekasi. Jurnal Kajian Komunikasi, 6(2), 204. https://doi.org/10.24198/jkk.v6i2.16712.

Jaka, I. N., Wiratama, A., \& Sintaasih, D. K. (2013). Pengaruh Kepemimpinan, Diklat, Dan Disiplin Kerja Terhadap Kinerja Karyawan Pdam Tirta Mangutama Kabupaten Badung. Jurnal Manajemen, Strategi Bisnis Dan Kewirausahaan, 7(2), 126-134. https://doi.org/10.24843/MATRIK:JMBK.

Kale, J. R., Ryan, H. E., \& Wang, L. (2019). Outside employment opportunities, employee productivity, and debt discipline. Journal of Corporate Finance, 59, 142-161. https://doi.org/10.1016/j.jcorpfin.2016.08.005.

Manik, S. (2017). Pengaruh Kepuasan Kerja Terhadap Disiplin Kerja Pegawai Kantor Camat Pendalian Iv Koto Kabupaten Rokan Hulu. International Journal of Social Science and Business, 1(4), 257. https://doi.org/10.23887/ijssb.v1i4.12526.

Palupi J, P. (2018). Pengaruh Motivasi Kerja, Disiplin Kerja, Dan Gaya Kepemimpinan Terhadap Kinerja Pegawai Di Lingkungan Rumah Sakit St. Carolus Summarecon Serpong. JENIUS (Jurnal Ilmiah $\begin{array}{llll}\text { Manajemen Sumber } \quad \text { Daya 133-145. } & \text { 1(2), }\end{array}$ https://doi.org/http://dx.doi.org/10.32493/JJSDM.v1i2.926.

Prabowo, W. A., \& Romadlon, F. (2020). Faktor Pengaruh Tingkat Kepuasan Kinerja Pramugari Perusahaan Transportasi Bis Joglosemar (PT. Sejahtera AO Kencana Sakti). Jurnal Manajemen Dan Keuangan, 9(1), 48-59. https://doi.org/10.33059/jmk.v9i1.2492.

Sintaasih, D., \& Astitiani, N. L. P. S. (2019). Peran Mediasi Knowledge Sharing Pada Pengaruh Quality of Work Life Dan Kepuasan Kerja Terhadap Kinerja Karyawan. Matrik: Jurnal Manajemen, Strategi Bisnis Dan Kewirausahaan, https://doi.org/https://doi.org/10.24843/MATRIK:JMBK.2019.v13.i01.

Suryani, N. L. (2020). Pengaruh Pengembangan Karir Dan Disiplin Terhadap Kepuasan Kerja Karyawan Pada PT. Qeon Interactive - Jakarta Pusat. JENIUS Uurnal Ilmiah Manajemen Sumber Daya Manusia), 3(2), 208. https://doi.org/10.32493/jjsdm.v3i2.3939.

Thamotharan, N., Majid, A. H. A., \& Jamaluddin, N. A. (2021). Influence of Quality of Work Life, Perceived Union Effectiveness and Job Security on Union Commitment Among Bank Employees. Jurnal Manajemen Dan Kewirausahaan, 23(1), 76-83. https://doi.org/https://doi.org/10.9744/jmk.23.1.76-83.

Viotti, S., Sottimano, I., Converso, D., \& Guidetti, G. (2020). The relationship between psychosocial characteristics of the work environment and job satisfaction in an Italian public ECE service: A cross-lagged study. Early Childhood Research Quarterly, 53, 464-475. https://doi.org/10.1016/j.ecresq.2020.06.002.

Wolomasi, A. K., Werang, B. R., \& Asmaningrum, H. P. (2019). Komitmen Kerja dan Pengaruhnya Terhadap Semangat dan Kepuasan Kerja Guru Sekolah Dasar. Musamus Journal of Primary Education, 2(1), 13-23. https://doi.org/10.35724/musjpe.v2i1.1572.

Yasa, N. N. K., Rahmayanti, P. L. D., Widani, I. A. P., Sugianingrat, S., Dharmanegara, I. B. A., \& Suharto, R. B. (2021). Peran perilaku inovatif dan komitmen organisasional memediasi pengaruh kebahagiaan kerja terhadap kinerja karyawan. MIX: Jurnal Ilmiah Manajemen, 11(2), 258-273. https://publikasi.mercubuana.ac.id/index.php/Jurnal_Mix/article/view/11720/pdf. 